\title{
Colorblind ideology, mass incarceration, and controlling racial images: An intersectional analysis of presidential rhetoric from 1969-1996
}

\author{
Adele N. Norris Ph.D. \& Joseph Billings B.A.
}

To cite this article: Adele N. Norris Ph.D. \& Joseph Billings B.A. (2016): Colorblind ideology, mass incarceration, and controlling racial images: An intersectional analysis of presidential rhetoric from 1969-1996, Journal of Ethnicity in Criminal Justice, DOI: 10.1080/15377938.2016.1256847

To link to this article: http://dx.doi.org/10.1080/15377938.2016.1256847

Accepted author version posted online: 07

Nov 2016.

Published online: 07 Nov 2016

Submit your article to this journal $\pi$

IIl Article views: 58

View related articles

View Crossmark data $\asymp$ 


\title{
Colorblind ideology, mass incarceration, and controlling racial images: An intersectional analysis of presidential rhetoric from 1969-1996
}

\author{
Adele N. Norris Ph.D. ${ }^{a}$ and Joseph Billings B.A. ${ }^{b}$ \\ a'Social Policy and Women's and Gender Studies, University of Waikato, Hamilton, New Zealand; \\ ${ }^{\mathrm{b}}$ Sociology, University of Minnesota-Twin Cities, Minneapolis, Minnesota, USA
}

\begin{abstract}
Ample research exists on the relationship between mainstream constructions of racialized images and perceptions of criminals. Fewer studies, however, have assessed the influence of political rhetoric in the construction and the mobilization of images of criminals as the "racial other." This study employs a qualitative content analysis guided by an intersectionality framework to answer the questions: to what extent Presidential rhetoric influenced images of criminals; and how was colorblind language used to facilitate this process? The examination of Presidential speeches related to crime policies, given from 1969 to 1996 , revealed that criminal activity was primarily articulated as being committed by "young Black impoverished males." Through the use of colorblind strategies, race, while not explicitly referenced, was the most salient dimension of the imagery of criminals depicted in Presidential rhetoric.
\end{abstract}

\section{ARTICLE HISTORY}

Received 6 February 2016

Revised 7 October 2016

Accepted 1 November 2016

\section{KEYWORDS}

Colorblind ideology; controlling images; intersectionality; mass incarceration

\section{Introduction}

In 1964, the Civil Rights Act was passed and crime was placed on the governmental agenda (Oliver, 1998). The former prohibited legal discrimination on the basis of race, while the latter smuggled racial discriminatory practices back onto the governmental agenda (Alexander, 2012). The latter created an inextricable link between the President and crime issues in the United States, whereby crime emerged as a national issue (Caplan, 1973). Michelle Alexander (2012) argues that the passage of the Civil Rights Act signaled both the end of a legal/policy era wherein the language of discriminatory policy explicitly incorporated race, and the start of an ideological shift into the age of colorblindness. The transition into more racially coded language that is not explicitly racist on the surface opened the doors for the criminal justice system to function, in many ways, like Jim Crow (Alexander, 2012; Davis, 1997; Toobin, 2016).

CONTACT Adele N. Norris annorris@waikato.ac.nz 0 Social Policy and Women's and Gender Studies, University of Waikato, Hamilton 3240, New Zealand.

๑) 2016 Taylor \& Francis Group, LLC 
Colorblind ideology has an extensive history in the United States. Some critical race scholars date colorblind rhetoric back to the 1896 Plessy v. Ferguson ruling (Collins, 2000; Crenshaw, 1991), which upheld racial segregation under the doctrine of Blacks and Whites being "separate but equal" (Collins, 2000, p. 277). Today, colorblindness is a racial ideology that informs the manner in which laws and public policies are written and enforced (Gomer, 2014). Manifested through the erroneous belief that merely talking about race fosters racism (Alexander, 2012; Bonilla-Silva, 2014; Collins, 2004; Gomer, 2014; Vargas, 2014), colorblind ideology has been deployed paradoxically to perpetuate and even deepen racist practices (Flynn, 2016), with the mass incarceration of persons of color being one of the most pressing social justice issue of the 21st century (Alexander, 2012; Davis, 2014; Heise, 2014; Kilgore, 2015). As colorblind ideology reinforces institutionalized racism, it simultaneously neutralizes the radical critique of racist practices (Pitcher, 2011).

The crux of Michelle Alexander's (2012) seminal analysis of mass incarceration in the United States is to show how colorblind ideology has been mobilized to mask the discriminatory nature of crime policies that have disproportionately impacted African Americans. She argues that the effect correctional policies have had on African Americans relies heavily on controlling racial images. Such a strategy does not require the explicit reference to race in order to mobilize racial biases. Even more concerning and important to emphasize is the fact that colorblind strategies have become a common feature of contemporary racism (Bonilla-Silva, 2014; Collins, 2000; Gallagher, 2008). Therefore, understanding contemporary racism demands an investigation of contemporary controlling images. Since controlling images of criminals are overwhelmingly of young, poor, Black males, understanding controlling images also requires an awareness of the overlapping nature of social constructs.

Intersectionality is a concept, a framework, and a methodology that considers the fluid nature of individuals' identities (Barak, Flavin, \& Leighton, 2001; Collins, 2000; Crenshaw, 1991; McCall, 2005; Norris, 2012). Within the context of crime, the way race, gender, and class intersect, shapes the perceptions of crime, the nature of criminal behavior, and the opportunities to commit other types of crimes (Barak, Flavin, \& Leighton, 2001). Intersecting social identities even influence the types of people considered criminals (Barak, Flavin, \& Leighton, 2001; Roberts, 1993; Toobin, 2016). For example, Roberts' (1993) intersectional examination of crime, race, and reproduction explains that the interconnectedness of racism and patriarchy functions as mutually reinforcing systems of domination that help determine "who the criminals are, what constitutes a crime, and which crimes society treats most seriously" (as cited in Barak, Flavin, \& Leighton, 2001, p. 16). Hence, intersecting social identities not only inform individuals' lived experiences, but also how others view them. Imagery also suggests that a link exists between representation and realities.

Studies investigating the media's influence on the construction of the stereotype of "the dangerous black male" found that Blacks appear in the media more often 
as criminally threatening, thus encouraging a social construction of threat in relation to Blacks (Collins, 2004; Hallet, 2006; Oliver, 1994; Welch, 2007; Barlow, 1998). Paradoxically, the core stereotypes of Black males as aggressive and criminal have not only remained, but also become culturally embedded in the era of colorblindness (Toobin, 2016). Enduring negative perceptions of Blacks throughout history is far from a new discussion, especially within the context of crime policies. Just as the supporters of chattel slavery created controlling images of the mule, jezebel, breeder woman, and the buck to justify the economic exploitation of Blacks (Collins, 2004; hooks, 1981), the same effects persist today with the perceptions of criminals as the "racial other." Even more concerning is White dominant society's receptivity to the image of a young Black male as a criminal threat, which crosses national boundaries (Toobin, 2016; Davis, 2014; Welch, 2007; Hallet, 2006).

The global promotion of images of criminals as the "racial other" has increased in importance with the expansion of for-profit mechanisms of social regulation (Davis, 2014; Hallet, 2006). Disenfranchised people, often invisible and socially reviled groups, are often targets of private, multinational, corporate enterprises which act much like the U.S. nineteenth century for-profit imprisonment, the "Convict Lease" system (Davis, 2014; Hallett, 2006). Hallett (2006) describes the quagmire of the Thirteenth Amendment which simultaneously abolished slavery and enabled the continuation of racialized forced labor in the South through the “Convict Lease" system from 1865-1920s:

With white southern elites caught between the legal restrictions of abolition and the paramount need for cheap labor, Convict Leasing emerged as a uniquely southern solution for solving this postbellum labor shortage-and a powerful vehicle for the continuation of white supremacy (p. 2).

Comparable to its precursor, the contemporary private contracting of prisoners for work fosters incentives to increase imprisonment (Davis, 2014; Pelaez, 2014), which involves the disproportionate captivity of poor Black men (Davis, 2014; Hallett, 2006). The appeal of not having strikes, unions, sick days, or late arrivals and not having to pay unemployment, health insurance, vacations, or compensatory time has attracted a variety of corporate investors, who lobby for longer sentences (Pelaez, 2014). It is argued that the global expansion of private prisons is not only legitimated by, but is also facilitated by the promotion of the images of criminals as the racial other (Hallett, 2006).

Collins $(2004 ; 2000)$ defines controlling images as stereotypical and degrading images that operate to exploit and justify "defective" characteristics of a particular group such as cultural inferiority. She argues that negative, controlling images limit or constrain authentic perceptions of disenfranchised groups, especially Black males. Within the context of crime, Welch (2007) maintains that ingrained images of criminals as young Black males are firmly rooted in White society's consciousness that "race does not even need to be specifically mentioned for a connection to be made between the two" (p. 276). It is for this reason Welch (2007) argues that it 
is important to understand the images of criminals constructed by dominant political and ideological discourses because a discussion of crime is, in fact, a discussion of race.

Political rhetoric has also been found to be a strong influence on public perceptions of crime (Cohen, 1997; Oliver, 1998; Schneider \& Ingram, 1993), especially that expressed by the President, the most visible U.S. politician (Cohen, 1997; De Castella \& McGarty, 2011; Oliver, 1998). High-profile presidential speeches on a specific policy problem have been found to elevate that problem to the public's consciousness (Oliver, 1998). From influencing views on welfare, civil rights, and the use of force to inciting the public's fear of crime and terrorism, the President's capability to shape the public's views through speeches can be quite significant (Cohen, 1997; De Castella \& McGarty, 2011; Esch, 2010; Oliver, 1998). For example, when it comes to issues of crime, Oliver (1998) found that the use of symbolic speeches and statements informed the public of what to think about by simply mentioning a "crime problem" exists. His study revealed that the more attention presidents gave to the issue of crime, the more the public concern increased. By mentioning crime over and over again, presidents were able to heighten public concern and fear of crime. Oliver (1998) concluded that presidential rhetoric's influence on public concerns about crime was far more reaching than either the media or reports of the official crime rate. With viewers into the tens of millions, the President's State of the Union address is used for the purpose of increasing media attention for a particular issue (Shogan, 2015).

If presidential speeches can impact the public's concern about crime, then presidential speeches can clearly influence presumably the public's perceptions of criminals. This present study examines the influence presidential rhetoric has had on the construction of the images of "criminals." Combining a qualitative content analysis guided by an intersectionality framework advanced by Leslie McCall (2005), this article builds on the growing body of scholarship which calls for a critical examination of colorblindness in an assumed post-racial society. Even more importantly, given the current racial climate surrounding the recent murders of young unarmed African Americans at the hands of law enforcement agents, understanding the contemporary construction of racial images at the intersections of race, gender, class, and age is an issue that is both timely and important. Therefore, a related goal of this paper is to argue for the integration of intersectional frameworks in the investigation of twenty-first century mass incarceration and controlling racial images.

\section{Literature review}

To understand the shaping of controlling images of criminals via presidential rhetoric, this study draws from four bodies of scholarship: Mass incarceration, colorblind ideology, controlling images, and intersectionality. This review begins by providing a fundamental understanding of what is meant by mass incarceration, giving emphasis to groups affected in disparate numbers. From this basis, it delves 
into a critical examination of colorblindness, linking it to mass incarceration and controlling images. This section concludes with an outline of this study's theoretical framework, intersectionality, which highlights the value of pointing a critical lens toward intersecting social identities in an effort to better understand mass incarceration.

\section{U.S. mass incarceration and the war on drugs}

The United States today leads the world's incarceration rates. Comprising only 5 percent of the world's population, the United States holds 25 percent of the world's prison population (Kelly, 2015; Pelaez, 2014), with rates higher today than in any other point in history (Alexander, 2012). Pager (2007) refers to the thirty-year time period after 1972 as the "prison boom" (p. 11). Between 1972 and 1984 the inmate population in the United States doubled, doubling again between 1984 and 1994. Before the 1970s, the prison population remained moderately constant with a little over 100 inmates per 100,000 residents. Near the end of the century, incarceration rates climbed to 486 per 100,000, resulting in 2 million individuals behind bars and 4.9 million individuals under the supervision of the criminal justice system (Pager, 2007). African Americans comprised 40 percent of the prison population when they only represent 12 percent of the U.S. population (Pager, 2007). These unprecedented rates of imprisonment coupled with the disproportionate representation of African Americans gave rise to mass incarceration, a complex system with devastating consequences (Bourne, 2007). The concept not only describes high levels of imprisonment, but also the residual effects of social exclusion (Alexander, 2012; Christian \& Thomas, 2009; Davis, 2014; Wehr \& Aseltine, 2013). For example, once an individual is labeled a criminal and/or a felon, he/she is stripped of the same rights supposedly won in the civil rights movement such as the right to vote, the right to serve on juries, and the right to be free of legal discrimination in employment, housing, and access to education and public benefits (Alexander, 2012).

However, the impact on the Black community in losing these rights is ever more significant. The character of today's penal policies, according to Lichtenstein (cited in Hallett, 2006, p. 1) is “found in America's intertwined histories of prisons, penal reform, and racism." While there is a massive push to dismiss race as a factor driving mass imprisonment (Alexander, 2012; Lichtenstein, 2001; Tonry, 2011), African Americans, compared to other racial or ethnic groups, are disproportionately represented in the criminal justice system (Alexander, 2012; Christian \& Thomas, 2009; Davis, 2014; Tonry, 2011; Bourne, 2007). In an era of pervasive colorblind ideology, poor, young, Black, males are targets of tough crime policies and initiatives (Alexander, 2012; Welch, 2007).

The social construction of a target population refers to the recognition of shared characteristics that distinguishes a target population as socially meaningful wherein values, symbols, stereotypes, and images are attributed to the target group 
(Schneider \& Ingram, 1993). Such constructions, according to Schneider and Ingram (1993), become embedded in policy as messages that are, in turn, absorbed by citizens. An example of the social construction of a targeted population is seen following the passage of the Civil Rights Act. During this time, issues such as civil disobedience, crime, and drugs were elevated to levels of national prominence (Alexander, 2012; Cohen, 1997; Oliver, 1998). The creation of the controlling images of targeted populations first stigmatized African Americans as criminals (Provine, 2007). Then incarceration rates among African Americans spiked upwards with the implementation of policies associated with the "war on drugs" (Alexander, 2012; Hallett, 2006). With effects so profound, Alexander (2012) argues that Black and brown individuals are born into a system in which they are targeted by the police at young ages primarily for non-violent and drug-related crimes, which are the very sorts of crimes that occur with roughly equal frequency in middle-class, White communities, and on college campuses, but largely ignored (Heise, 2014).

Michael Tonry's (2011) study of racial disparities in imprisonment revealed that Blacks do not use drugs at higher rates than Whites nor sell drugs more often than Whites; however, police arrest Blacks for drug dealing much more often than Whites. The same trend is seen in the arrest rates of Black drug users. Whites are also far less likely to be convicted or imprisoned for drug use. For example, in 1980, adult drug arrests per 100,000 people for Whites were 367 and 684 for Blacks. In 2003, the rates increased to (70\%) 658 for Whites and to (225\%) 2,221 for Blacks (Cohen, 1997; Tonry, 2011). The imprisonment of Blacks at disproportionate rates is even more profound among males age 18 or older, with one in every 15 being incarcerated compared to one in every 106 of their White counterparts (Cohen, 1997).

Congress explanation for crack-cocaine sentencing rival disparity is based on the rationale that crack offenders largely operate outdoors, thus damaging communities, whereas cocaine dealers and users tend to be more covert in their dealings (Alexander, 2012). Access to good legal defense, which is related to poverty, has long been identified as a structural issue exacerbating the disparities between Black and White arrest rates (Alexander, 2012; Cohen, 1997). Some scholars, however, have attributed the vast inequalities in arrest rates to White privilege granted to Whites at every stage of the criminal justice system for committing the same crimes as Blacks (Hughey, 2014; Pager, 2003). Yet, racial discrimination at the structural level has been minimized as an explanatory factor (Alexander, 2012).

\section{Colorblind ideology and controlling images}

Colorblind ideology has increasingly contributed to ambivalent attitudes toward race in the United States, and thus the continued erasure of race from discussions of social inequalities (Bonilla-Silva, 2014; Burke, 2014; Davis 1997; Vargas, 2014). Packaged as contemporary racial common sense, colorblindness conceals White privilege behind a guise of assumed meritocracy. At the same time, it renders 


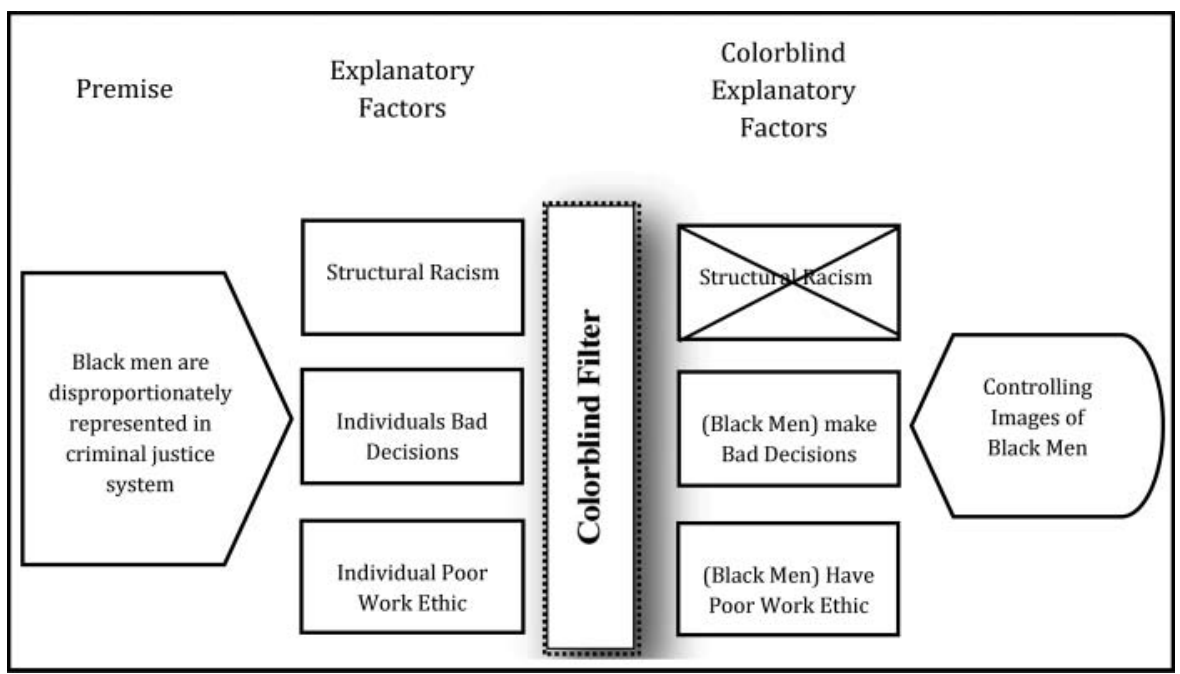

Figure 1. Graphical depiction of the mobilization process of controlling images of black males through colorblind filters.

invisible the institutional arrangements that perpetuate racial inequality (BonillaSilva, 2014; Burke, 2014; Pitcher, 2011; Vargas, 2014). Institutional racism, as a result, no longer registers at societal conscious level, but rather the controlling images of the types of individuals who commit crimes. Figure 1 depicts this process.

Colorblindness, also a component of contemporary racism, detaches the legacies of historical forms of racism from explanations of contemporary social problems (Alexander, 2012; Burke, 2014; Vargas, 2014). Alexander (2012) clearly articulates the importance of investigating mass incarceration as not only a contemporary issue, but also as a legacy of historical systems of racial control. For instance, in an interview with The Society Pages, Alexander states that contemporary explanations of high incarceration rates among Black and brown people cycling in and out of prison are bad schools, broken homes, and poverty. However, the problem lies in the fact that while incarceration rates have increased over the past few decades, poor communities of color have always had bad schools and high poverty rates (Heise, 2014).

\section{Theoretical framework: Intersectionality}

Thus far, this discussion has illuminated how the manifestation of colorblind ideology presents major challenges to grappling with the far-reaching consequences mass incarceration has had on African Americans (Alexander, 2012; Bonilla-Silva, 2014; Hallet, 2006). However, there have been fewer studies that investigate the role of interlocking social oppressions (e.g., race, gender, and class) in the construction and maintenance of contemporary controlling images. Intersectionality, a concept, theoretical framework, and methodology, offers a useful lens through 
which to examine controlling images and mass incarceration. Having roots in Black feminism, intersectionality motivates us to recognize how certain identities are socially constructed at the expense of others, thereby creating different types of lived experiences, social realities, and stereotypes (Collins, 2000; Crenshaw, 1991; McCall, 2005; Norris, 2012; Norris, Murphy-Erby, Green, Willis, \& Jones, 2013). Not only does having a mindset attuned to the interlocking nature of oppression facilitate our understanding of the fluid nature of social identities, but it also enhances our understanding of how certain populations are more vulnerable to being negatively stereotyped. For example, being poor, young, Black and, in the case of correctional policies, male, increase an individual's powerlessness to reverse the negative images assigned to them.

\section{Intersectionality and mass incarceration}

As an alternative paradigm, intersectionality has been increasingly used by legal and criminal justice scholars to examine the experiences of mass incarceration across different racial/ethnic groups. For example, with African-American women's unparalleled proximity to the phenomenon, researchers argue that situations specific to Black women's experiences with mass incarceration are still marginalized (Foster, 2011; Ocen, 2013). Ocen (2013) argued that failing to engage an intersectionality framework within legal scholarship on mass incarceration obscures the centrality of Black women's gender in the racialized system of control. Christian and Thomas's (2009) exploration of African-American women's unique challenges in the era of mass imprisonment as both incarcerated women and women connected to imprisoned men and women found that grandparent caregiving is higher for African-American women than for any other group. Moreover, Black women experience secondary prisonization as visitors of incarcerated family members at higher rates than other groups. These studies all illuminate the complexities of mass incarceration at the intersection of multiple social identities and the necessity of considering an intersectional framework in the investigation of racial images, including those construed within presidential speeches.

\section{Method}

To understand the influence of presidential rhetoric on the construction of racial images, this study employs qualitative content analysis, specifically a directed inductive approach, guided by an intersectionality framework. Qualitative content analysis has been widely used to analyze text by focusing on characteristics of language as communication, with special attention devoted to the content or contextual meaning of the text (Hsieh \& Shannon, 2005). Researchers interested in probing political rhetoric have used content analysis to investigate fear-arousing content in political rhetoric from top political figures (see DeCastella \& McGarty, 2011; Esch, 2010). For example, Perry (2011) used content analysis to examine political rhetorical strategies of Black mayors of majority-white cities in their 
Table 1. Presidential speeches selected for analysis.

\begin{tabular}{|c|c|c|c|}
\hline Date & President & Title & Words \\
\hline 7/14/1969 & Richard Nixon & $\begin{array}{l}\text { Special Message to the Congress on Control of Narcotics } \\
\text { and Dangerous Drugs }\end{array}$ & 2,380 \\
\hline $6 / 17 / 1971$ & Richard Nixon & $\begin{array}{l}\text { Remarks About an Intensified Program for Drug Abuse } \\
\text { Prevention and Control }\end{array}$ & 696 \\
\hline 7/17/1971 & Richard Nixon & Special Message to the Congress on Drug Control & 5,278 \\
\hline 9/14/1986 & Ronald Reagan & $\begin{array}{l}\text { Address to the Nation on the Campaign Against Drug } \\
\text { Abuse }\end{array}$ & 2,934 \\
\hline 9/5/1989 & $\begin{array}{l}\text { George H. W. } \\
\text { Bush }\end{array}$ & $\begin{array}{l}\text { Address to the Nation on the National Drug Control } \\
\text { Strategy }\end{array}$ & 2,979 \\
\hline $1 / 25 / 1994$ & Bill Clinton & State of the Union Address & 7,293 \\
\hline $1 / 23 / 1996$ & Bill Clinton & State of the Union Address & 6,331 \\
\hline
\end{tabular}

efforts to represent interests pertinent to African Americans, while Fording and Smith (2012) explored presidential rhetoric to examine President Obama's leadership in tackling issues of poverty.

Since the objective of this study is to assess the social construction of images of individuals/groups targeted in correctional policies across diverse groups, this study uses McCall's (2005) intersectionality methodology, intercategorical approach. This approach is ideal because it begins with the observation that there are relationships of inequality among already constituted social groups. Thus, these relationships become the center of analysis. So, for example, gender (men and women) will be cross classified with social class (lower, working, middle, and upper) and race.

\section{Data sample}

This study's sample includes seven presidential speeches (see Table 1) retrieved from the American Presidency Project website (http://www.presidency.ucsb.edu/). The selected speeches explicitly discuss correctional policies and were delivered by Presidents Nixon, Reagan, Bush, and Clinton from 1969 through to 1996. This specific time period was chosen because it follows the passing of the Civil Rights Act in 1964, which officially ended Jim Crow Laws, the last legal form of racial control. Alexander (2012) refers to this period as the era of mass incarceration and colorblindness. It was also during this time period when the most comprehensive Crime Control Acts in the U.S. history were passed and the nation experienced a prison boom.

\section{Coding procedure}

The authors divided the analysis into three phases. The first phase consisted of a review of relevant literature for themes related to the goals of this study. Given the extensive body of research on correctional policies in the United States, this process furnished key thematic concepts and phrases for the initial coding process and the development of a code sheet: (a) violence/drug/crime problem in the United States; (b) individuals or groups who engage in drug-related criminal activity; and (c) national response/punishments for drug related activity. The second phase involved the analysis of presidential speeches. Of the seven speeches, there 
Table 2. Themes and subthemes revealed by qualitative content analysis of presidential speeches related to correctional policies.

\begin{tabular}{|c|c|}
\hline Themes & Subthemes \\
\hline Drug use elevated to national prominence & $\begin{array}{l}\text { - Criminal activity related to drugs use/abuse } \\
\text { - Severity of the problem } \\
\text { - Types of drugs discussed }\end{array}$ \\
\hline $\begin{array}{l}\text { Descriptions of drug users/abusers and at } \\
\text { risk populations }\end{array}$ & $\begin{array}{l}\text { - Addicts, traffickers, at risk populations } \\
\text { - Attributes/Characteristics of addicts } \\
\text { - Emphasis on specific locations/ environments } \\
\text { associated with drug use } \\
\text { - Anecdotes } \\
\text { - Individuals in need protection }\end{array}$ \\
\hline National response to threat of drugs & $\begin{array}{l}\text { - Penalties/Punishment } \\
\text { - "Americans"' Responsibility }\end{array}$ \\
\hline
\end{tabular}

were a total of 274 statements containing the words crime, drug(s), and violence. Twenty randomly selected statements were coded by each coder and then discussed. Given the authors reached a consensus regarding the codes assigned to the 20 statements, the authors began coding the remainder of the statements for each president. This process revealed ten additional sub-themes (see Table 2). After the speeches were coded, the authors, in phase three, organized codes into categories that reflected race, gender, social class, and age according to the intercategorical approach in which the main task was to explicate the relationships among multiple social groups within and across analytical categories. For example, terms such as street(s)/housing development were coded as being both urban (U) and lower social class (LSC). Similarly, localities/settings such as suburbs were coded as middle social class (MSC) and non-urban (NU). If there were more middle class and male references for a particular theme, then it was determined that middle class men were associated more with the action discussed. Codes appearing in equal amounts across analytical categories indicated that no one analytical category was emphasized more than another.

\section{Trustworthiness and reliability}

The use of existing literature informed this study, specifically during the initial coding procedure. Therefore, the possibility of biases introduced inherent limitation. The authors attempted to reduce bias by meeting regularly to discuss emergent themes and codes. All phases of the investigation were discussed in several research sessions among authors. Special attention was devoted to assessing relevant literature for emergent themes and the application of the theoretical framework, intersectionality, in an effort to minimize biases.

\section{Results}

This section presents the findings of this study's content analysis. Results are presented according to key emergent themes and sub-themes. Emphasis is devoted to the social categories, race, gender, class and age. 


\section{Drug and criminal activity: A national problem}

The analysis revealed that drug abuse was described in terms of being the gravest threat to American life and greatest social problem in American history. For example: "America's public enemy number one in the United States is drug abuse" (Nixon, June 17, 1971). Words such as "dangerous," "threat," "terror," "menace," "enemy," "horror," "grave," "epidemic," and "evil" were used more than once to describe the United States drug problem. Second, while drug use was deemed a national problem that had "assumed the dimensions of a national emergency" (Nixon, June 17, 1971), the underlying causes for drug abuse were described as being associated with individual character flaws such as being lazy or a result of poor choices. Structural issues, such as racial inequalities, unemployment rates, and discriminating housing policies, were omitted. Third, the connection of drug abuse with criminal activity was established through labels such as "addict(s)," "drug criminals," and "crack gangs." These labels were immediately followed by a description of the corresponding criminal activities for which "addicts" engage:

The habit of the narcotics addict is not only a danger to himself, but a threat to the community where he lives. Narcotics have been cited as a primary cause of the enormous increase in street crimes over the last decade ... As the addict's tolerance for drugs increases, his demand for drugs rises, and the cost of his habit grows. It can easily reach hundreds of dollars a day. Since an underworld "fence" will give him only a fraction of the value of goods he steals, an addict can be forced to commit two or three burglaries a day to maintain his habit. Street robberies, prostitution, even the enticing of others into addiction to drugs-an addict will reduce himself to any offense, any degradation in order to acquire the drugs he craves (President Richard Nixon, July 14, 1969).

The bolded text highlights the descriptors given to anyone who engages in drug use, the crimes addicts commit, the addicts' gender, and the location from which addicts commit crime.

\section{Criminal activity}

Criminal activity was described primarily in terms exclusive to metropolitan areas, cities, and streets. By the late 1980s and 1990s, rhetoric associated with street/city life was violence, crime, unwed mothers, drugs, unemployment, absent fathers, and gangs. Terms that were not used in reference to urban drug use, except to note their absence were family, community, civilization, and American. This was further revealed though statements that it is the public's responsibility or it is "American" to support tough crime policies in order to establish the right values in such dire places. President Bill Clinton, in his State of the Union Address stated:

My fellow Americans ... I urge you to consider this: As you demand tougher penalties for those who choose violence, let us also remember how we came to this sad point. In our toughest neighborhoods, on our meanest streets, in our poorest rural areas, we have seen a stunning and simultaneous breakdown of community, family, and work, 
the heart and soul of civilized society. This has created a vast vacuum which has been filled by violence and drugs and gangs (January 25, 1994).

And so tonight, let us resolve to continue the journey of renewal, to create more and better jobs, to guarantee health security for all, to reward work over welfare, to promote democracy abroad, and to begin to reclaim our streets from violent crime and drugs and gangs, to renew our own American community (January 25, 1994).

With the exception of one reference, which referred to the "poorest" rural areas, "rural areas" and "suburbs" were rarely stated in relation to drug use or criminal activity.

\section{Penalties}

Penalties or the type of actions demanded to defeat the national enemy, drug abuse, emerged as a major theme. Each president, for over 15 years, described penalties for drug-related activities as being too weak to be effective, and therefore demanded new tactics encompassing harsher and tougher punishments and more money. President Nixon set up the movement toward harsher penalties with pronouncements such as the following ones:

Society has few judgments too severe, few penalties too harsh for the men who make their livelihood in the narcotics traffic (July 14, 1969).

In order to fight and defeat this enemy [drug abuse], it is necessary to wage a new, all-out offensive (June 17, 1971).

I am transmitting legislation to the Congress to consolidate at the highest level a fullscale attack on the problem of drug abuse in America ... I will ask for additional funds to increase our enforcement efforts to further tighten the noose around the necks of drug peddlers (June 17, 1971).

President Bush in his September 5, 1989 Address to the Nation on the National Drug Control Strategy, acknowledges some success with the Reagan administration's efforts on correctional policies, but asserts that more is needed, especially in terms of monetary funds:

[O]ver the past 6 months of careful study, we have found an immediate need for another billion and a half dollars. With this added $\$ 2.2$ billion, our 1990 drug budget totals almost $\$ 8$ billion, the largest increase in history ... those who judge our strategy only by its price tag simply don't understand the problem. Let's face it, we've all seen in the past that money alone won't solve our toughest problems. To be strong and efficient, our strategy needs these funds. But there is no match for a united America, a determined America, an angry America. Our outrage against drugs unites us, brings us together behind this one plan of action-an assault on every front.

President Clinton, in his 1994 State of the Union Address, follows this trend by emphasizing the urgency to pass crime policies that will yield immediate results to mitigate the crime problem:

My fellow Americans, the problem of violence is an American problem ... Therefore, I urge you to find ways as quickly as possible to set aside partisan differences and pass a strong, smart, tough crime bill. 


\section{Drug use/abuse: Race, gender, social class, and age}

Drug abuse/use was discussed under the following five categories: (1) social costs to society/laws/policies, (2) international influences, (3) at-risk populations, (4) penalties/punishments, and (5) individual users and abusers. Of the five main categories, individuals abusing drugs received the most attention wherein drug abusers were described in terms of the general American public, the military, males, and youth. However, emphasis was devoted to drug abuse among populations living in urban environments/streets and in cities with large minority populations. The military, for example, was mentioned in five statements related to crime as opposed to over 70 statements linking crime primarily to the streets, cities, housing developments, and gangs:

Narcotics have been cited as a primary cause of the enormous increase in street crimes over the last decade (President Richard Nixon, Special Message to the Congress on Control of Narcotics and Dangerous Drugs, July 14, 1969).

And while illegal drug use is found in every community, nowhere is it worse than in our public housing projects ... And that's why I'm targeting $\$ 50$ million to fight crime in public housing projects-to help restore order and to kick out the dealers for good. (President George H. W. Bush, Address to the Nation on the National Drug Control Strategy, September 5, 1989).

I read a newspaper story about a little boy named Dooney who, until recently, lived in a crack house in a suburb of Washington, D.C. (President George H. W. Bush, September 5,1989 ).

This is crack cocaine seized a few days ago by Drug Enforcement agents in a park just across the street from the White House ... It's as innocent-looking as candy, but it's turning our cities into battle zones, and it's murdering our children (President George H. W. Bush, September 5, 1989).

And I challenge local housing authorities and tenant associations: Criminal gang members and drug dealers are destroying the lives of decent tenants (President Bill Clinton, January 23, 1996).

Our fourth great challenge is to take our streets back from crime and gangs and drugs (President Bill Clinton, January 23, 1996).

While phrases such as drug abuse "cuts across all generations," "universal problem," and "drug abuse has swept across America" were used by all presidents, they were stated sparingly in comparison to locating the drug/crime problem on the streets and in cities with large African-American populations such as Washington, D.C., Philadelphia, Oakland, St. Louis, Los Angeles, Houston, and New York. The repeated emphasis placed on housing developments and the streets as the prime location of the nation's drug problem carries with it an inherent implication that the problem has a lower social-class status, as do explicit descriptions of this "massive" problem being primarily orchestrated by inner-city gangs. These iterations evoke images of minority populations, specifically African-Americans, although African-American/Black is never mentioned. Correspondingly, such deliberate pinpointing exonerates other locations (e.g., rural, suburban), populations (e.g., White) and social classes (e.g., middle and 
upper) as part of the drug problem, but rather positions them as key players in the solution.

\section{Youth and drug abuse}

The explicit references to young populations were consistent. Youth emerged in terms of being identified as an at-risk population, drug users, and weapon owners:

We cannot renew this country when 13-year-old boys get semi-automatic weapons to shoot 9-year-olds for kicks (President Bill Clinton, January 25, 1994).

The terms "addict" and "drug abuser" were primarily described as a young male except in cases describing young unwed mothers addicted to drugs:

And when hundreds of thousands of babies are born each year to mothers who use drugs - premature babies born desperately sick - then even the most defenseless among us are at risk (George H.W. Bush, September 5, 1989).

I spoke with a businessman named Jim Burke who said he was haunted by the thought-a nightmare, really-that somewhere in America, at any given moment, there is a teenage girl who should be in school instead of giving birth to a child addicted to cocaine (George H.W. Bush, September 5, 1989).

Statements regarding drug prevention programs, drug rehabilitation, and gang violence referenced young adults, children, teenagers, juveniles, and students. With the few exceptions of college students referenced by President Richard Nixon, youth and young adults were given the most emphasis with regard to drug use and violent crime. This group was also described as residing in lower social-class environments. Emphasis was also placed on the allure of drugs as the chief barrier preventing youth from achieving a bright future. Absent from the rhetoric were statements regarding the social forces that placed youth in housing developments prior to the drug problem:

Between the years 1960 and 1967, juvenile arrests involving the use of drugs rose by almost 800 percent; half of those now being arrested for the illicit use of narcotics are under 21 years of age (President Nixon, July 14, 1969).

Regular drug use is even higher among the age group 18 to $25-$ most likely just entering the workforce (President Reagan, September 14, 1986).

No one among us is out of harm's way. When 4-year-olds play in playgrounds strewn with discarded hypodermic needles and crack vials, it breaks my heart. When cocaine, one of the most deadly and addictive illegal drugs, is available to school kids-school kids-it's an outrage (George H.W. Bush, Address to the Nation on the National Drug Control Strategy, September 5, 1989).

\section{Race, drugs, and excluded populations}

As stated earlier, specific racial/ethnic groups were not explicitly identified in the discussions of crime and drug use; however, themes of race were implied via anecdotes and the overwhelming references to urban cities, public housing projects, and crack gangs.

Crack users and dealers were labeled as being more threating and in need of tougher sentencing than other types of drug users. The reference to crack use as 
only occurring in housing developments and streets associates this drug with a poorer social class population (cheaper/lower social class) as opposed to cocaine (more expensive/higher social class). Such use of language implies that Blacks are the primary crack smokers; hence the sole source of rising crime rates and drug use:

Today there's a new epidemic: smokable cocaine, otherwise known as crack. It is an explosively destructive and often lethal substance which is crushing its users. It is an uncontrolled fire ... Our job is never easy because drug criminals are ingenious. They work every day to plot a new and better way to steal our children's lives, just as they've done by developing this new drug, crack (President Ronald Reagan, September 14, 1986).

Our most serious problem today is cocaine, and in particular, crack (George H.W. Bush, September 5, 1989).

And that's why habitual cocaine users, especially crack users, are the most pressing, immediate drug problem (George H.W. Bush, September 5, 1989).

Race (Black) and social class (poor) association with criminal activity were also implied via the exclusion of descriptions of White, poor, and middle-class populations in discussions of drug abuse. While cocaine was stated, it was in general terms. Cocaine users were not identified nor was cocaine connected to a specific location in the same way as crack:

And while illegal drug use is found in every community, nowhere is it worse than in our public housing projects. You know, the poor have never had it easy in this world. But in the past, they weren't mugged on the way home from work by crack gangs. And their children didn't have to dodge bullets on the way to school. And that's why I'm targeting $\$ 50$ million to fight crime in public housing projects-to help restore order and to kick out the dealers for good (George H. W. Bush, September 5, 1989).

The exclusion of "family" within the context of drug abuse emerged as an important theme in the construction of the targeted population. Infrequent statements such as "[d]rugs are a real and terribly dangerous threat to our neighborhoods, our friends, and our families" (Bush, 1989) makes it sound as if there is no particular face attached to drug abuse. Anyone could be affected. However, a closer analysis revealed that drug abusers were primarily articulated as fatherless males, and young unwed teen mothers who lack the proper direction to make sound decisions, which would come from being reared in a proper family:

We can't renew our country when children are having children, and the fathers walk away as if the kids don't amount to anything (President Bill Clinton, January 25, 1994).

This framing of drug abusers as individuals who are not members of nuclear families refined the construction of the target population for correctional policies. (1) Since large numbers of African Americans reside in the cities and environments referenced as problem areas not just in terms of drugs, but also as single mothers on welfare, this group was in turn constructed as not being members of 
proper families and lacking family values. Such unconventional familial structures were not only presented as an underclass phenomenon, but also a threat to the values that equate to being American. (2) Poor African-American males, especially those living in low-income environments, were implicitly constructed as drug users, gang members, and individuals who engage in criminal activity by their association regardless of their actual behavior. (3) Whites, by default, were positively stereotyped as being members of nuclear families, having the proper values to make sound decisions that prevent them from drug use. Thus, Whites were implicitly exonerated from the social construction of threatening groups for which correctional policies are needed, by virtue of their geographical distance from the problem areas constructed as the prime locations of concern.

\section{The use of anecdotes}

Anecdotes were used similarly across the presidents' speeches. The explicit marking of social class and gender, and the implicit marking of race was consistent in each anecdote. Also, consistent is that the anecdotes located the "drug problem" in a very specific place that affected a specific group of people, often implicitly Black youth:

Not long ago, I read a newspaper story about a little boy named Dooney who, until recently, lived in a crack house in a suburb of Washington, D.C. In Dooney's neighborhood, children don't flinch at the sound of gunfire. And when they play, they pretend to sell to each other small white rocks that they call crack. Life at home was so cruel that Dooney begged his teachers to let him sleep on the floor at school. And when asked about his future, 6-year-old Dooney answers, "I don't want to sell drugs, but I'll probably have to."

Well, Dooney does not have to sell drugs. No child in America should have to live like this. Together as a people we can save these kids. We've already transformed a national attitude of tolerance into one of condemnation. But the war on drugs will be hard-won, neighborhood by neighborhood, block by block, child by child (President George H. W. Bush, September 5, 1989).

\section{Discussion}

The results revealed that there were not any explicit references to race. Rather, the use of geographical locations and anecdotes describing the drug problem painted a picture of a specific group of people who resided in poor environments, and cities, spaces that are widely known to be predominantly Black. The exclusion of references to non-urban environments and populations worked to eliminate Whites, specifically middle-class Whites from the construction of "drug user," "dealer," "thief," "gang member," and "lawless individual." Additionally, such omissions implicitly conveyed the message that Whites, particularly middle-class Whites were the groups in need of protection from the "national enemy," drug use, which was described as occurring almost exclusively in urban hubs. 
This exercise of power via the implicit referencing of race is arguably more difficult to combat than blatant forms of racial discrimination. For example, President Nixon's Special Message to the Congress on Control of Narcotics and Dangerous Drugs frames the issue of drug abuse as a major national problem associated with a lack of societal order. While no significant policy change accompanied this event, it set the political agenda to establish crime control as a major political issue that set the stage for later policy changes (Alexander, 2012). During this time period, popular media images of the Civil Rights Movement facilitated the construction of the image of young Black males as perpetrators of lawlessness, riots, and looting. The violence in Black neighborhoods is framed as a conflict between the "lawlessness" represented by Black rioters and protestors, and the preservation of societal order upheld by White police officers (Alexander, 2012; Barlow, 1998). The Nixon Administration, as Alexander describes, set a precedent of using race-neutral language to indirectly further a racially-motivated agenda by constructing and capitalizing on racialized images and stereotypes of African Americans to mobilize the political biases of poor Whites through juxtaposition of the "hard-working blue collar White family" with the welfare-dependent Black family.

Presidents Reagan and Bush capitalized on the Nixon Administration's shift in a racially biased methodology and further developed coded ways of talking about race, in particular Blacks, in the public forum. This colorblind approach insulated the administration from claims of racially discriminatory motivations (Alexander, 2012). For example, colorblind rhetoric is used to explain away sentencing disparities. The Anti-Drug Abuse Act of 1986 created 100 to 1 Cocaine to Crack minimum sentencing guidelines, established the death penalty for some drug crimes, and increased anti-drug funding by two billion USD (Barak, Flavin, \& Leighton, 2001; Tonry, 2011). The results reveal that the rhetoric was also used to single out crack as a more dangerous drug, requiring much harsher penalties than other forms of narcotics. This application of a colorblind filter removes race as a link in the causal chain of racial disparities in incarceration rates. Instead, a colorblind explanation posits that crime is a result of individual bad decisions and/or individual poor work ethic. Thus, if Blacks are overrepresented among crime statistics and incarceration rates, then these character flaws must be highly prevalent among Blacks. This reasoning reinforces controlling racial images that associate Blacks with crime and also ascribes to this group micro-level explanation of crime such as poor judgement or laziness as opposed to macro/structural level explanations.

President Bill Clinton's rhetoric on correctional policies revealed an explicit continuation of the previous administration's imagery of criminals as the "racial other." Shortly prior to and during President Clinton's administration, research showed that in 1991 the majority of Americans believed Blacks were more prone to violence (Alexander, 2012; Oliver, 1998). This widespread mentality sets the stage for a war on violent crime that is completely devoid of explicit racial language, yet supported by racial bias (Alexander, 2012; Oliver, 
1998). The Violent Crime Control and Law Enforcement Act of 1994 implemented a "3-strikes" initiative that mandated a life-sentence for a third felony, expanded the use of death penalty, and allocated 30 billion USD to increase state level law enforcement and to build new prisons. In addition to expanding punishment for drug crimes and increasing enforcement, this legislation also provided the foundation for the full emergence of the private prison market in the United States. This Act comes during a time when public opinion surveys revealed crime, particularly violent crime, to be the most important issue in the country (Oliver, 1998).

In summary, the explicit references to the social categories other than race served as triggers to cue society of a particular racial group, in this case, African Americans. This understanding illuminates the interlocking workings of social categories. The explicit references of social class (poor), gender (male) and age (age) linked to an urban environment made it possible to exclude explicit references of race and still target a specific racial group.

\section{Conclusion}

This article used a content analysis combined with an intersectionality framework to analyze presidential speeches during a critical time in the United States during which the harshest crime bills were passed and the mass incarceration of African Americans reached unprecedented numbers. This study found that racially-coded language was used to depict the "other" as the source of the crime problem. Within this rhetoric, African Americans were frequently implicitly construed as both a threat to law and order, and to the patriarchal organization of the nuclear family. Because race was not mentioned, this study shows that at the very core of the notion of colorblindness is the reverse.

This analysis builds on discussions that argue for the value of an intersectionality framework in the examination of mass incarceration. The covert nature of colorblind racism transitions it to a power dimension even more insidious than historical forms of overt racial control (e.g., Jim Crow). As Collins (2000) explains, power exists in legislative and policy actions that both shape controlling images, as well as rely upon their existence to mobilize bias to garner support for political action. This manifestation of colorblindness within the structural domain (Collins, 2000) and the hegemonic domain (Bonilla-Silva, 2014) serves today as the ideological armor for covert racial biases. It is also within these domains that racialized images of criminals as young, Black, impoverished males are shaped and mobilized through the influence of coded language (Collins, 2000).

This issue is of major importance because colorblind ideology is deployed to deepen the ideologies, intuitions, and practices of contemporary racism (Alexander, 2012; Bonilla-Silva, 2014; Collins, 2004; Vargas, 2014), which "rejects overt interpersonal racial prejudice and discrimination" (Vargas, 2014, p. 2283). Understanding this discursive strategy will better elucidate the workings of contemporary 
racism. As Collins (2004) maintains, contemporary racism relies heavily on the manipulation of ideas within mass media, which in turn filters into the common sense of popular belief.

Thus, future research is needed as we enter into an era of exploring the social cost of these get tough policies that extends beyond the prison. While this study analyses the presidential rhetoric during a twenty-five-year period when the harshest crime policies were passed and incarceration rates spiked, it is important to note that the social cost of mass incarceration began to hit home during the early part of the century. President George W. Bush, during his 2004 State of the Union address, acknowledged near the end of his speech the challenges former prisoners faced re-entering society, focusing specifically on employment (Pager, 2007). Pager (2007) states that President George W. Bush was a strong advocate of a tough on crime approach but what had changed was the somber recognition of the social costs associated with those crime policies. The mounting social cost of mass imprisonment reached the government agenda during President Barak Obama's term. For example, the social costs of imprisonment have manifested in disrupted families/communities, increased foster care needs, and grandparent caregiving, former inmates finding quality employment, and mounting psychological cost of stigma associated with being a felon have spurred a national debate. In multiple addresses, President Obama has emphasized the need for prison reform (Hudson, 2015).

Lastly, by employing an intersectionality framework to explore the construction of racial images in political rhetoric, this study expands upon the key findings of other works, which suggest that controlling images share an inextricable link with colorblind strategies. Contemporary colorblind racism, according to Collins (2006, p. 3) "claims not to see race yet manages to replicate racial hierarchy as effectively as the racial segregation of old."

\section{References}

Alexander, M. (2012). The new Jim Crow: mass incarceration in the age of colorblindness (Rev. ed). New York, NY: New Press.

Barak, G., Flavin, J., \& Leighton, P. (2001). Class, race, gender, and crime: Social realities of justice in America. Los Angeles, CA: Roxbury Publishing Company.

Barlow, M. H. (1998). Race and the problem of crime in "Time" and "Newsweek" cover stories, 1946 to 1995. Social Justice, 25(2), 149-183.

Bonilla-Silva, E. (2014). Racism without racists: color-blind racism and the persistence of racial inequality in America (Fourth edition). Lanham: Rowman \& Littlefield Publishers, Inc.

Bourne, R. W. (2007). Richardson v. Ramirez: A motion to reconsider. Valparaiso University Law Review, 42(1), 1-31.

Burke, M. A. (2014). Colorblindness vs. race-consciousness: An American ambivalence. In D. Hartmann \& C. Uggen (Eds.), Color lines and racial angles (pp. 165-176). New York, NY: W. W. Norton.

Caplan, Gerald. (1973). Reflections on the nationalization of crime, 1964-1968. Arizona State University Law Journal, 3, 583-635. 
Christian J. \& Thomas, S. (2009). Examining the intersections of race, gender, and mass imprisonment. Journal of Ethnicity in Criminal Justice, 7, 69-84.

Cohen, J. E. (1997). Presidential responsiveness and public policy-making: The public and the policies that presidents choose. Ann Arbor, MI: University of Michigan Press.

Collins, P. H. (2000). Black feminist thought: knowledge, consciousness, and the politics of empowerment (Rev. 10th anniversary ed.). New York, NY: Routledge.

Collins, P. H. (2004). Black sexual politics: African Americans, gender, and the new racism. New York, NY: Routledge.

Collins, P. H. (2006). From black power to hip hop: Racism, nationalism, and feminism. Philadelphia, PA: Temple University Press.

Crenshaw, K. (1991). Mapping the margins: Intersectionality, identity politics and violence against women of color. Stanford Law Review 46(6), 1241-1299.

Davis, A. Y. (1997). Race and criminalization: Black Americans and the punishment industry. In Lubiano Wahneema (Ed.), The house that race built (pp. 264-279). New York, NY: Random House, Inc.

Davis, A. Y. (2014). Deepening the debate over mass incarceration. Socialism and Democracy, 28 (3), 15-23.

De Castella, K. \& McGarty, C. (2011). Two leaders, two wars: A psychological analysis of fear and anger content in political rhetoric about terrorism. 11(1), 180-200.

Esch, J. (2010). Legitimizing the "War on Terror": Political myth in official-level rhetoric. Political Psychology, 31(3), 357-391.

Flynn, A. (2016). The rules are not neutral: "Colorblind" policies drive racial inequality. Roosevelt Institute. Retrieved August 20, 2016 from http://rooseveltinstitute.org/rules-not-neutralcolorblind-policies-drive-racial-inequality/

Fording, R. C. \& Smith, J. L. (2012). Barack Obama's "fight" to end poverty: Rhetoric and reality. Social Science Quarterly, 93(5), 1161-1181.

Foster, H. (2011). The influence of incarceration on children at the intersection of parental gender and race/ethnicity: A focus on child living arrangements. Journal of Ethnicity in Criminal Justice, 9(1), 1-21.

Gallagher, C. A. (2008). "The end of racism” as the New Doxa: New strategies for researching race. In T. Zuberi \& E. Bonilla-Silva (Eds.), White logic, White methods: Racism and methodology (pp. 163-178). Lanham, MD: Rowman \& Littlefield.

Gomer, J. D. (2014). Colorblindness, a life: Race, film and the articulation of an ideology (Unpublished doctoral dissertation). Berkeley, CA: University of California.

Hallett, M. A. (2006). Private prisons in America: A critical race perspective. Urbana, IL: University of Illinois Press.

Heise, K. (2014). Exposing the new Jim Crow with Michelle Alexander. In D. Hartmann \& C. Uggen (Eds.), Color lines and racial angles (pp. 177-190). New York, NY: W.W. Norton.

hooks, b. (1981). Ain't I a woman: Black women and feminism. Boston, MA: South End Press.

Hsieh, H. \& Shannon, S. E. (2005). Three approaches to qualitative content analysis. Qualitative Health Research, 15(9), 1277-1288.

Hudson, D. (2015). President Obama: "Our criminal justice system isn't as smart as it should be.” The White House. Retrieved August 20, 2016 from https://www.whitehouse.gov/blog/ 2015/07/15/president-obama-our-criminal-justice-system-isnt-smart-it-should-be

Hughey, M. W. (2014). Beyond the big, bad racist: Shared meaning of white identity and supremacy. In D. Hartmann \& C. Uggen (Eds.), Color lines and racial angles (pp. 65-80). New York, NY: W. W. Norton.

Kelly, P. (2015). Mass incarceration. Public Health Nursing, 32(1), 1-2.

Kilgore, J. (2015). Mass incarceration: Examining and moving beyond the new Jim Crow. Critical Sociology, 41(2), 283-295. 
McCall, L. (2005). The complexity of intersectionality. Signs: Journal of Women in Culture and Society, 30(3), 1771-1800.

Norris, A. N. (2012). Rural women, anti-poverty strategies and black feminist thought. Sociological Spectrum, 32, 449-461.

Norris, A. N., Murphy-Erby, Y., Green, A., Willis, K., Jones, T. (2013). An intersectional exploration: The experiences of southern, rural, black and white women participating in an empowerment-based entrepreneurial program. Intersectionalities: A Global Journal of Social Work Analysis, Research, Polity, and Practice, 2, 88-106.

Ocen, P. A. (2013). Unshackling intersectionality. Du Bois Review, 10(2), 471-483.

Oliver, M. B. (1994). Portrayals of crime, race, and aggression in "reality-based" police shows: A content analysis. Journal of Broadcasting \& Electronic Media, 38(2), 179-192.

Oliver, W. M. (1998). Presidential rhetoric on crime and public opinion. Criminal Justice Review, 23(2), 139-160.

Pager, D. (2007). Marked: Race, crime, and finding work in an era of mass incarceration. Chicago, IL: University of Chicago Press.

Pelaez, V. (2014). The prison industry in the United States: Big business or a new form of slavery? Global Research. Retrieved May 5, 2015 at http://www.globalresearch.ca/the-prisonindustry-in-the-united-states-big-business-or-a-new-form-of-slavery/8289

Perry, R. K. (2011). Kindred political rhetoric: Black mayors, President Obama, and the universalizing of black interests. Journal of Urban Affairs, 33(5), 567-589.

Pitcher, B. (2011). Radical subjects after hegemony. Subjectivity, 4(1), 87-102.

Provine, D. M. (2007). Unequal under law race in the war on drugs. Chicago, IL: University of Chicago Press.

Roberts, D. E. (1993). Crime, race, and reproduction. Tulane Law Review, 67(6), 1945-1977.

Schneider, A. \& Ingram, H. I. (1993). Social construction of target populations: Implications for politics and policy. American Political Science Review, 87(2), 334-347.

Shogan, C. J. (2015). The President's State of the Union Address: Tradition, function, and policy implications. Congressional Research Service. Retrieved from www.crs.gov

Tonry, M. H. (2011). Punishing race: A continuing American dilemma. New York, NY: Oxford University Press.

Toobin, J. (2016). The legacy of lynching, on death row. The New Yorker, 1-16. Retrieved from http://www.newyorker.com/magazine/2016/08/22/bryan-stevenson-and-the-legacy-of-lynch ing

Vargas, N. (2014). Off white: Colour-blind ideology at the margins of whiteness. Ethnic and Racial Studies, 37(13), 2281-2302.

Wehr, K., \& Aseltine, E. (2013). Beyond the prison industrial complex crime and incarceration in the 21st century. New York, NY: Routledge.

Welch, K. (2007). Black criminal stereotypes and racial profiling. Journal of Contemporary Criminal Justice, 23(3), 276-288. doi:10.1177/1043986207306870 